\title{
Seasonal and Annual Changes in Biomass Nitrogen and Carbon of Mesquite and Palo Verde Ecosystems
}

\author{
R.C. BARTH AND J.O. KLEMMEDSON
}

\begin{abstract}
Biomass components of mesquite (Prosopis juliflora(Swartz)DC) and palo verde (Cercidium floridum (Benth)) soil-plant systems were collected during spring, winter, and fall for 3 years to study the temporal distribution of the mass of understory vegetation and litter and the dynamics of nitrogen and carbon in all biomass components. Mass of palo verde litter changed seasonally while that of mesquite did not change. With exception of mesquite litter, mass of understory vegetation and litter did not change annually for either shrub. Seasonal and annual changes were observed in both $N$ and $C$ of selected shrub, understory, and litter components, but these changes were more prevalent in mesquite than palo verde. Seasonal changes appeared primarily related to $\mathbf{N}$ and $\mathbf{C}$ demand in regions of rapid growth. Annual changes appear related to weather phenomena which regulate decomposition, uptake, and growth.
\end{abstract}

Research on shrubs has been extensive in the western United States. It has covered a broad subject matter (McKell et al. 1972) including productivity, value as browse, reestablishment, control or removal of unwanted species, and other subjects. Several studies have examined the carbohydrate dynamics of shrubs (Coyne and Cook 1970, Menke and Trlica 1983) and some have looked at nutrient relations of soil-plant systems (Garcia-Moya and McKell 1970, Youngberg and $\mathrm{Hu}$ 1972, Tiedemann and Klemmedson 1973, Klemmedson 1979), mostly from the standpoint of nutrient cycling and nitrogen fixation.

Studies of the internal nutrient dynamics of woody species have concerned either silviculturally important trees (e.g., Sampson and Samisch 1935, Mitchell 1936, Tamm 1951) or horticultural crops (Kelley and Shier 1965, Hansen 1967, Meyer and Splittstoesser 1969). Comparable studies on western shrubs have emphasized value of shrubs as herbivore browse (Dietz 1972).

Research reported here was part of a larger study of nitrogen and carbon distribution in soil-plant systems of important shrubs of the Sonoran Desert, much of which has been previously reported (Barth and Klemmedson 1978, 1982). The objective of the research reported here was to measure seasonal and annual changes of nitrogen $(\mathrm{N})$ and carbon $(\mathrm{C})$ in shrub and understory components of velvet mesquite (Prosopis juliflora (Swartz) DC) and blue palo verde (Cercidium floridum Benth)) ecosystems.

\section{Study Area}

The study area was at the Santa Rita Experiment Range about $32 \mathrm{~km}$ south of Tucson, Ariz. The study site, a grass-shrub community typical of this part of the Upper Sonoran Desert, was selected for its uniformity. It was located at $975 \mathrm{~m}$ elevation on an alluvial plain with slopes of 1 to $5 \%$. Velvet mesquite and palo verde were the dominant woody species. Both shrubs occurred on upland sites, but shrub density was greater along numerous arroyos that dissect the plain. Mature velvet mesquite shrubs averaged $3 \mathrm{~m}$ height and had from 1 to 3 main stems; mature palo verde shrubs were slightly smaller and were generally single stemmed.

\footnotetext{
Authors are senior research ecologist, Colorado School of Mines Res. Inst., Golden Authors are senior research ecologist, Colorado School of Mines Res. Inst., Golden
80401 ; and professor, School of Renewable Natural Resources, Univ. of Arizona, Tucson 85721 .

This article is a contribution of the School of Renewable Natural Resources, Univ. of Arizona, Tucson 85721. Research supported by Nat. Sci. Found. Grant No. GB-15866 to the Desert Biome Program, US/IBP, in cooperation with the Arizona Agr. Exp. Sta., Journal Árticle No. 3995.

Manuscript accepted 21 June 1985.
}

Understory vegetation was dominated by Arizona cottontop Digitaria californica (Benth.) Chase, needle grama (Bouteloua aristidoides H.B.K.), bush muhly (Muhlenbergia porteri Scribn.) and burroweed Aplopappus tenuisectus (Green) Blake. Sampling was restricted to upland sites and to the Sonoita soil series. This soil is derived from recent mixed alluvial deposits and is a loamy, mixed thermic Typic Haplargid. For the previous 50 years, the site had been lightly and uniformly grazed; disturbance from other causes was not visible.

\section{Field Methods}

Thirty-four velvet mesquite and 24 palo verde shrubs were randomly selected from a large pool of candidate shrubs encompassing the size range of each species and sampled at phenologically similar seasons each year according to the following schedule: 1971, five mesquite in spring (May) and fall (Sep. - Oct.); 1972, five mesquite and five palo verde in winter (Feb.), spring (Apr.-May), and fall (Sep.-Oct.; 1973, three mesquite and three palo verde in winter (Jan.), spring (May), and fall (Sep.). Recognizing the large inherent variation of range ecosystems, field sampling was designed to hold environmental factors other than time variables constant or to vary within narrow limits. For each shrub sampled, six 0.093 $\mathrm{m}^{2}$ plots were located on a north-south line running through the center of the shrub. Understory vegetation and litter were sampled in these plots under the shrub canopy at points $1 / 3,2 / 3$, and $3 / 3$ of the north and south canopy radii (CR). At each plot location live and dead standing understory vegetation was collected separately by harvesting plants at ground level. Litter from the overstory shrub (shrub litter) and from the understory vegetation (understory litter) also was collected from each plot. Material collected from north and south sides of each shrub was combined, by positions, thus making the combined plots $0.186 \mathrm{~m}^{2}$ in size. Weighted means for each shrub component were calculated based on the area represented by the sample for each canopy position under each shrub.

Shrub roots were extracted from $8 \times 10 \mathrm{~cm}$ soil columns collected to $60 \mathrm{~cm}$ depth under each vegetation-litter plot and from a plot located at each shrub center. Samples from comparable north and south plots of each shrub were combined; weighted means for shrubs were calculated as above.

Each shrub was harvested at ground level and separated into leaves, flowers, fruit, current growth (woody growth $<1$ year old), branches $<1 \mathrm{~cm}$ in diameter, branches $>1 \mathrm{~cm}$ diameter, and deadwood. Branches and deadwood were weighed in the field to the nearest $0.5 \mathrm{~kg}$; other components were weighed to the nearest gram. Random samples were taken of all shrub components for moisture content and laboratory analyses.

Samples were oven-dried at $70^{\circ} \mathrm{C}$, weighed, and ground to pass a 40-mesh screen. Total $\mathbf{N}$ was determined by macro-Kjeldahl (Bremner 1965). Organic $C$ was determined by dry combustion in a high-frequency induction furnace (Allison et al. 1965).

Analysis of variance and separation of means by Duncan's new multiple range test for significant effects were performed at the 0.05 probability level.

\section{Results and Discussion}

\section{Seasonal Changes in Ecosystem Components Mass}

The mass of understory vegetation beneath mesquite and palo 
Table 1. Mass of understory vegetation, shrub litter, and understory litter for velvet mesquite and palo verde ecosystems by seasons and years.

\begin{tabular}{|c|c|c|c|c|c|c|}
\hline \multirow[b]{2}{*}{ Component } & \multicolumn{3}{|c|}{ Seasonal } & \multicolumn{3}{|c|}{ Year } \\
\hline & Spring & Fall & Winter & 1971 & 1972 & 1973 \\
\hline & \multicolumn{5}{|c|}{ Velvet Mesquite Ecosystem } & \\
\hline $\begin{array}{l}\text { Understory vegetation' } \\
\text { Mesquite litter } \\
\text { Understory litter }\end{array}$ & $\begin{array}{l}148 a^{2} \\
271 a \\
157 a\end{array}$ & $\begin{array}{l}119 a \\
346 a \\
144 a\end{array}$ & $\begin{array}{l}162 \mathrm{a} \\
255 \mathrm{a} \\
143 \mathrm{a}\end{array}$ & $\begin{array}{l}103 a \\
143 b \\
167 a\end{array}$ & $\begin{array}{l}166 \mathrm{a} \\
360 \mathrm{ab} \\
128 \mathrm{a}\end{array}$ & $\begin{array}{l}130 a \\
497 a \\
159 a\end{array}$ \\
\hline $\begin{array}{l}\text { Understory vegetation' } \\
\text { Palo verde litter } \\
\text { Understory litter }\end{array}$ & $\begin{array}{l}308 \mathrm{a} \\
271 \mathrm{a} \\
260 \mathrm{a}\end{array}$ & $\begin{array}{l}188 \mathrm{a} \\
129 \mathrm{ab} \\
256 \mathrm{a}\end{array}$ & $\begin{array}{l}\text { Palo } \\
154 a \\
113 b \\
329 a\end{array}$ & $\begin{array}{c}\text { stem } \\
- \\
-\end{array}$ & $\begin{array}{l}296 \mathrm{a} \\
143 \mathrm{a} \\
266 \mathrm{a}\end{array}$ & $\begin{array}{l}166 a \\
296 a \\
244 a\end{array}$ \\
\hline
\end{tabular}

IValues for understory vegetation are weighted means of standing live and standing dead vegetation.

Within any row for seasonal or annual data, values that lack one or more common letters are significantly different at the $p<0.05$ level.

verde did not change significantly from season to season (Table 1), evidently reflecting the 2 growing seasons of the Sonoran Desert and high variance among the population sampled. The primary growing season occurs during summer when herbaceous perennials maximize growth. A second growing season occurs in winter or early spring for shrubs, succulents, and annual herbs if sufficient winter precipitation is received (Martin 1964). Most herbaceous perennials make little growth during this season (Culley 1943). Apparently these different growing seasons created a rather constant standing crop of understory vegetation from season to season.

Mass of palo verde litter declined significantly between spring and winter (Table 1), thus reflecting the shedding of fruit and small branches between the winter and spring sampling dates and accelerated decomposition during summer (Santos and Whitford 1981). By contrast, there was no difference among seasons for mesquite litter. Shedding of leaves and fruit of mesquite was not distinctly seasonal. In some years leaves were shed in December, while in other years leaves were retained until late spring. Small dead branches were shed at all seasons and may have masked the expected rapid decomposition during summer.

Litter derived from the understory vegetation showed no significant seasonal pattern for either shrub. The transfer of understory litter from standing crop to litter occurred throughout the year, thus keeping the mass of understory litter relatively constant.

\section{Nitrogen}

Leaves and current growth of mesquite and palo verde displayed significant seasonal changes in percentage $\mathrm{N}$ (Table 2 ). The decline in $\mathrm{N}$ concentration from a spring peak began some time after the spring flush of growth and continued into winter dormancy; seasonal decline of $\mathrm{N}$ in leaves is commonly observed (Tamm 1951, Grigal et al. 1976). Protein turnover can be rapid in young leaves (Bidwell 1979) as well as in older storage organs (McKee 1962, Meyer and Splitstoesser 1969). These nitrogen reserves are translocated in spring to regions of actively growing tissue and metabolized to support new growth (Meyer and Splittstoesser 1969). Losses of leaf $\mathrm{N}$ through leaching by precipitation also may contribute to the observed pattern (Tukey 1970).

Table 2. Nitrogen and carbon for components of velvet mesquite and palo verde ecosystems by seasons.

\begin{tabular}{|c|c|c|c|c|c|c|}
\hline \multirow[b]{2}{*}{ Ecosystem component } & \multicolumn{3}{|c|}{ Nitrogen } & \multicolumn{3}{|c|}{ Carbon } \\
\hline & Spring & Fall & Winter & Spring & Fall & Winter \\
\hline & \multicolumn{6}{|c|}{ Velvet Mesquite Ecosystem } \\
\hline $\begin{array}{l}\text { Shrub Components } \\
\text { Leaves } \\
\text { Current growth } \\
\text { Branches }<1 \mathrm{~cm} \\
\text { Branches }>1 \mathrm{~cm} \\
\text { Roots }\end{array}$ & $\begin{array}{l}3.51 \mathrm{a}^{1} \\
2.27 \mathrm{a} \\
1.36 \mathrm{c} \\
1.03 \mathrm{c} \\
1.56 \mathrm{a}\end{array}$ & $\begin{array}{l}2.82 \mathrm{~b} \\
1.77 \mathrm{~b} \\
1.52 \mathrm{~b} \\
1.16 \mathrm{ab} \\
1.55 \mathrm{a}\end{array}$ & $\begin{array}{l}2.25 \mathrm{c} \\
2.00 \mathrm{ab} \\
1.74 \mathrm{a} \\
1.26 \mathrm{a} \\
1.52 \mathrm{a}\end{array}$ & $\begin{array}{l}46.7 \mathrm{a} \\
44.7 \mathrm{~b} \\
43.3 \mathrm{a} \\
42.8 \mathrm{a} \\
45.9 \mathrm{a}\end{array}$ & $\begin{array}{l}47.3 \mathrm{a} \\
45.9 \mathrm{a} \\
43.3 \mathrm{a} \\
43.3 \mathrm{a} \\
46.0 \mathrm{a}\end{array}$ & $\begin{array}{l}45.3 \mathrm{~b} \\
44.9 \mathrm{ab} \\
42.9 \mathrm{a} \\
41.7 \mathrm{~b} \\
45.3 \mathrm{a}\end{array}$ \\
\hline $\begin{array}{l}\text { Standing Understory2 } \\
\text { Vegetation } \\
\text { Shrub litter } \\
\text { Understory litter }\end{array}$ & $\begin{array}{l}1.08 \mathrm{~b} \\
1.64 \mathrm{ab} \\
1.17 \mathrm{a}\end{array}$ & $\begin{array}{l}1.21 \mathrm{a} \\
1.50 \mathrm{~b} \\
1.30 \mathrm{a}\end{array}$ & $\begin{array}{l}1.20 \mathrm{a} \\
1.73 \mathrm{a} \\
1.29 \mathrm{a}\end{array}$ & $\begin{array}{l}40.8 \mathrm{a} \\
40.0 \mathrm{a} \\
38.4 \mathrm{a}\end{array}$ & $\begin{array}{l}40.6 \mathrm{a} \\
38.6 \mathrm{~b} \\
36.6 \mathrm{~b}\end{array}$ & $\begin{array}{l}41.6 \mathrm{a} \\
40.6 \mathrm{a} \\
36.9 \mathrm{ab}\end{array}$ \\
\hline $\begin{array}{l}\text { Shrub Components } \\
\text { Leaves } \\
\text { Current growth } \\
\text { Branches }<1 \mathrm{~cm} \\
\text { Branches }>1 \mathrm{~cm} \\
\text { Roots }\end{array}$ & $\begin{array}{l}4.18 \mathrm{a} \\
3.20 \mathrm{a} \\
1.63 \mathrm{a} \\
1.15 \mathrm{a} \\
1.28 \mathrm{a}\end{array}$ & $\begin{array}{l}3.48 \mathrm{~b} \\
2.15 \mathrm{~b} \\
1.48 \mathrm{a} \\
1.19 \mathrm{a} \\
1.18 \mathrm{a}\end{array}$ & $\begin{array}{l}2 . \overline{48 b} \\
1.63 \mathrm{a} \\
1.02 \mathrm{a} \\
1.04 \mathrm{a}\end{array}$ & $\begin{array}{l}43.2 \mathrm{a} \\
43.5 \mathrm{a} \\
42.1 \mathrm{a} \\
42.9 \mathrm{a} \\
44.2 \mathrm{a}\end{array}$ & $\begin{array}{l}41.6 \mathrm{~b} \\
43.3 \mathrm{a} \\
42.6 \mathrm{a} \\
43.7 \mathrm{a} \\
44.1 \mathrm{a}\end{array}$ & $\begin{array}{l}-\overline{43.4 a} \\
42.2 \mathrm{a} \\
42.7 \mathrm{a} \\
44.0 \mathrm{a}\end{array}$ \\
\hline $\begin{array}{l}\text { Standing Understory } 2 \\
\text { Vegetation }\end{array}$ & $1.07 \mathrm{a}$ & $1.21 \mathrm{a}$ & $1.14 \mathrm{a}$ & $41.5 a$ & $41.4 a$ & $42.2 \mathrm{a}$ \\
\hline Shrub Litter & $1.44 \mathrm{a}$ & $1.31 \mathrm{a}$ & $1.31 \mathrm{a}$ & $38.8 \mathrm{a}$ & $37.2 \mathrm{~b}$ & $38.9 \mathrm{a}$ \\
\hline Understory Litter & $1.24 \mathrm{a}$ & $1.25 \mathrm{a}$ & $1.13 \mathrm{a}$ & $37.7 \mathrm{ab}$ & $36.2 \mathrm{~b}$ & $38.6 \mathrm{a}$ \\
\hline
\end{tabular}

1Within any given row for $\mathrm{N}$ or $\mathrm{C}$, figures that lack one or more common letters are significantly different at the $p<0.05$ level.

2 Values for standing understory vegetation are weighted means of standing live and standing dead vegetation. 
The decline in percentage $\mathrm{N}$ of current growth (twigs) during the early growing season is similar to that observed for other shrubs (Grigal et al. 1976) and horticultural species (Kelley and Shier 1965). This also can be associated with cyclic protein metabolism described above for leaves. This decrease also can be explained by the expected increase in structural carbohydrate as current growth takes on a woody character with the maturing process. Presumably, the two processes occur simultaneously.

Both small and large branches of mesquite had significantly lower $\mathrm{N}$ concentrations in the spring than in fall or winter (Table 2). Apparently, $\mathrm{N}$ in these components was translocated during spring to growing regions when demand for $\mathrm{N}$ was large. By fall and winter, $\mathrm{N}$ concentration had been restored in these woody tissues, presumably by translocation and resynthesis of proteins from regions of active photosynthesis and cyclic protein metabolism. This pattern was not evident in branches of palo verde; perhaps the higher $\mathrm{N}$ content associated with the photosynthesizing bark of this species masked seasonal translocation of $\mathbf{N}$. Moreover, growth (and perhaps $\mathrm{N}$ translocation) in palo verde appeared to be more related to actual periods of higher precipitation (Table 3) than to the seasonal sampling periods. We detected no seasonal changes in $\mathrm{N}$ content of roots for either species.

Standing vegetation in the understory of mesquite shrubs was significantly higher in $\mathbf{N}$ during the fall and winter than in spring (Table 2). The same trend occurred for palo verde, but differences were not significant; the smaller sample size, hence higher variance, for palo verde may have been responsible. Timeliness of $\mathbf{N}$ availability, growth stages of the vegetation, and seasonal differences in species composition may have been important factors in the low $\mathbf{N}$ concentration of understory vegetation in spring. Uptake of $\mathrm{N}$ by understory species can be expected to be higher during late summer
Table 3. Monthly precipitation for the study area.

\begin{tabular}{lrcr}
\hline \hline & \multicolumn{3}{c}{ Year } \\
\cline { 2 - 4 } Month & 1971 & 1972 & 1973 \\
\hline & 0 & 0 & 9 \\
Jan & 20 & 0 & 36 \\
Feb & 0 & 0 & 71 \\
Mar & 12 & 0 & 1 \\
Apr & 0 & 3 & 0 \\
May & 0 & 38 & 17 \\
June & 54 & 91 & 52 \\
July & 113 & 54 & 20 \\
Aug & 37 & 29 & 8 \\
Sep & 28 & 120 & 0 \\
Oct & 24 & 40 & 12 \\
Nov & 68 & 18 & 0 \\
Dec & 356 & 393 & 226 \\
Total & & & \\
\hline
\end{tabular}

and winter when soil moisture is more conducive to $\mathrm{N}$ mineralization than in spring when upper soil layers are normally dry. A spring understory vegetation composed of species characteristically lower in $\mathrm{N}$ percentage may be another factor contributing to low $\mathrm{N}$ percentage of the understory in spring. Nutrient dynamics of the complex understory vegetation defies simple explanation.

The $\mathrm{N}$ concentration of mesquite litter was higher in winter than in fall (Table 2). This seasonal pattern may have reflected differential shedding of plant components. Most mesquite leaves were shed in winter, thus enriching litter with $\mathbf{N}$. In fall, only scattered seed pods were added to litter. Tarrant et al. (1969) found seasonal changes in N content of red alder (Alnus rubra Bong.) litter and

Table 4. Nitrogen and carbon for components of velvet mesquite and palo verde ecosystems by years.

\begin{tabular}{|c|c|c|c|c|c|c|}
\hline \multirow[b]{2}{*}{ Ecosystem Component } & \multicolumn{3}{|c|}{ Nitrogen } & \multicolumn{3}{|c|}{ Carbon } \\
\hline & 1971 & 1972 & 1973 & 1971 & 1972 & 1973 \\
\hline & \multicolumn{6}{|c|}{ Velvet Mesquite Ecosystem } \\
\hline Shrub Components & & & & & & \\
\hline Leaves & $3.06 \mathrm{ab}^{\prime}$ & $2.96 \mathrm{~b}$ & $3.69 \mathrm{a}$ & $47.1 \mathrm{a}$ & $46.7 \mathrm{a}$ & $47.6 \mathrm{a}$ \\
\hline Flowers & $3.67 \mathrm{~b}$ & $3.16 \mathrm{~b}$ & $4.88 \mathrm{a}$ & $45.3 a$ & $43.6 \mathrm{~b}$ & $42.0 \mathrm{~b}$ \\
\hline Fruit & $2.33 \mathrm{a}$ & $2.45 a$ & $1.75 \mathrm{a}$ & $44.9 a$ & $43.6 \mathrm{a}$ & $44.3 \mathrm{a}$ \\
\hline Current growth & $2.11 \mathrm{ab}$ & $1.76 b$ & $2.28 \mathrm{a}$ & $46.0 \mathrm{a}$ & $44.9 \mathrm{a}$ & $44.8 \mathrm{a}$ \\
\hline Branches $<1 \mathrm{~cm}$ & $1.38 \mathrm{a}$ & $1.51 \mathrm{a}$ & $1.43 \mathrm{a}$ & $43.2 \mathrm{a}$ & $43.2 \mathrm{a}$ & $43.6 \mathrm{a}$ \\
\hline Branches $>1 \mathrm{~cm}$ & $1.21 \mathrm{a}$ & $1.11 \mathrm{a}$ & $0.87 \mathrm{~b}$ & $42.6 \mathrm{a}$ & $43.0 \mathrm{a}$ & $44.1 \mathrm{a}$ \\
\hline Roots & $1.47 \mathrm{a}$ & $1.48 \mathrm{a}$ & $1.82 \mathrm{a}$ & $44.3 \mathrm{c}$ & $46.4 b$ & $47.6 \mathrm{a}$ \\
\hline \multicolumn{7}{|l|}{ Standing Understory² } \\
\hline Vegetation & $1.07 \mathrm{~b}$ & $1.17 \mathrm{ab}$ & $1.23 \mathrm{a}$ & $42.4 \mathrm{a}$ & $38.9 \mathrm{~b}$ & 41.1a \\
\hline Shrub Litter & $1.49 \mathrm{a}$ & $1.58 \mathrm{a}$ & $1.68 \mathrm{a}$ & $40.2 \mathrm{a}$ & $38.9 \mathrm{a}$ & $38.4 \mathrm{a}$ \\
\hline \multirow[t]{2}{*}{ Understory litter } & $1.14 b$ & $1.14 b$ & $1.56 \mathrm{a}$ & $36.3 \mathrm{a}$ & $39.3 b$ & $36.7 \mathrm{a}$ \\
\hline & \multicolumn{6}{|c|}{ Palo Verde Ecosystem } \\
\hline \multicolumn{7}{|l|}{ Shrub Components } \\
\hline Leaves & - & $3.69 \mathrm{~b}$ & $4.51 \mathrm{a}$ & - & $42.1 b$ & $43.9 \mathrm{a}$ \\
\hline Flowers & - & $3.35 b$ & $3.91 \mathrm{a}$ & - & $45.8 \mathrm{a}$ & $44.9 \mathrm{a}$ \\
\hline Fruit & - & $3.07 \mathrm{a}$ & $2.55 \mathrm{a}$ & - & $44.5 \mathrm{a}$ & $44.7 \mathrm{a}$ \\
\hline Current Growth & - & $2.61 a$ & $2.78 \mathrm{a}$ & - & $43.4 a$ & $43.4 \mathrm{a}$ \\
\hline Branches $<1 \mathrm{~cm}$ & - & $1.50 \mathrm{a}$ & $1.65 \mathrm{a}$ & - & $42.3 a$ & $42.4 a$ \\
\hline Branches $>1 \mathrm{~cm}$ & - & $1.27 \mathrm{a}$ & $1.01 \mathrm{~b}$ & - & $43.1 \mathrm{a}$ & $43.5 \mathrm{a}$ \\
\hline Roots & - & $1.19 \mathrm{a}$ & $1.31 \mathrm{a}$ & - & $44.1 \mathrm{a}$ & $44.1 \mathrm{a}$ \\
\hline \multicolumn{7}{|l|}{ Standing Understory ${ }^{2}$} \\
\hline Vegetation & - & $1.02 \mathrm{~b}$ & $1.36 \mathrm{a}$ & - & $42.1 \mathrm{a}$ & $41.0 \mathrm{~b}$ \\
\hline Shrub Litter & - & $1.31 b$ & $1.49 \mathrm{a}$ & - & $38.4 \mathrm{a}$ & $37.5 \mathrm{a}$ \\
\hline Understory Litter & - & $1.10 \mathrm{~b}$ & $1.50 \mathrm{a}$ & - & $37.6 \mathrm{a}$ & $35.8 \mathrm{a}$ \\
\hline
\end{tabular}

I Within any given row for $\mathbf{N}$ or $\mathbf{C}$, figures that lack one or more common letters are significantly different at the $p<0.05$.

${ }^{2}$ Values for standing understory vegetation are weighted means for standing live and standing dead vegetation. 
attributed the differences to phenological events of the overstory. Bocock (1963) attributed the increase of $\mathrm{N}$ in forest litter from fall through spring to the seasonal pattern of $\mathrm{N}$ transfer from tree canopies via throughfall.

Nitrogen percentage of palo verde litter did not change seasonally. Leaf biomass of palo verde shrubs was only $12 \mathrm{~g} \mathrm{~m}^{-2}$ compared to $148 \mathrm{~g} \mathrm{~m}^{-2}$ for velvet mesquite. Addition of this small amount of palo verde leaves to the shrub litter had no measurable effect on its $\mathrm{N}$ concentration. Moreover, leaf shedding in palo verde appeared more dependent on precipitation events than on seasonal periods.

The $\mathrm{N}$ percentage of litter from understory vegetation for both velvet mesquite and palo verde did not change on a seasonal basis. Understory vegetation apparently contributed to litter throughout the year, thus maintaining a constant $\mathbf{N}$ concentration in the understory litter.

\section{Carbon}

Statistical analyses disclosed small but significant changes in percentage $C$ in 3 of 5 shrub components of mesquite but only in leaves of palo verde (Table 2 ). In mesquite, $C$ in leaves declined by about $2 \%$ from fall to winter, while that in current branches increased approximately $1 \%$ from spring to fall. Although these differences were statistically significant, it seems prudent to question their biological significance. The decline of $C$ in leaves could be associated with translocation or throughfall loss of water soluble carbohydrates or volatile fats and oils as leaves matured (Tukey 1970). The gain in C in current branches may have been associated with the gradual development of woody tissue as new twigs matured. Grigal et al. (1976) associated a simultaneous decline of leaf biomass and increase in stem biomass in fall with translocation of carbohydrates. Meyer and Splittstoesser (1969) observed rapid changes in carbohydrates of roots, stems and buds of lilac (Syringa vulgaris $\mathrm{cv}$. Charles Joly) during the spring flush of growth.

The decline in $\mathbf{C}$ percentage in large branches of mesquite from fall to winter (Table 2) was unexpected. We have no explanation for this change in $\mathrm{C}$ percentage in what would appear to be the most biologically stable component of the shrubs.

The $\mathrm{C}$ concentration of shrub and understory litter of both species reached their lowest levels in fall. Based on the work of Hopkins (1966), Comanor and Staffeldt (1978) and Santos and Whitford (1981), the $C$ percentage of litter on the Arizona desert should reach an annual low during late summer because of peak microbial decomposition during the hot summer rainy season. Similarly, the annual peak of $\mathrm{C}$ percentage in litter should occur following leaf fall and decline slowly until conditions suitable for rapid decomposition resume.

\section{Annual Changes}

\section{Mass}

Mass of standing understory vegetation did not change from year to year (Table 1), despite substantial differences in annual precipitation (Table 3). High variance among years undoubtedly contributed to this result. High production during wet periods apparently compensated for low production during dry periods within years, thus keeping the annual dry matter production fairly constant.

No annual differences were found in palo verde litter or the litter associated with understory vegetation beneath palo verde and velvet mesquite. Although litterfall of shrubs and understory vegetation may vary annually (we did not measure litterfall), differences are at least partially masked by litter accumulation of prior years. Work by Santos and Whitford (1981) suggests that annual decomposition does not consume the entire litter layer beneath shrubs in the Sonoran Desert. During the course of this study (1971 to 1973) there was a significant buildup of velvet mesquite litter (Table 1).

\section{Nitrogen}

Annual changes in the $\mathrm{N}$ concentration of shrub components were noted for both velvet mesquite and palo verde (Table 3).
Leaves, flowers and current growth of mesquite, and leaves and flowers of palo verde had significantly higher concentrations of $\mathbf{N}$ in 1973 than in 1972, but no differences were noted between 1971 and 1972. The high values recorded for 1973 appear associated with high precipitation during the Feb.-Apr. period of that year $(108 \mathrm{~mm})$ compared with the average $(16 \mathrm{~mm})$ for the similar periods in 1971 and 1972 (Table 3). It seems reasonable to argue that this large difference in precipitation could have resulted in a significantly different environment for mineralization and uptake of soil N.

Percentage $\mathrm{N}$ of large branches $(>1 \mathrm{~cm})$ was significantly lower in both mesquite and palo verde in 1973 than in the previous years (Table 4). This response may indicate a higher level of $\mathrm{N}$ mobilization and translocation out of large branches in 1973 than in 1971 and 1972 to satisfy the demand for increased $N$ in younger, growing tissues.

Standing understory vegetation of mesquite was higher in $\mathbf{N}$ in 1973 than in 1971 while that of palo verde was greater in 1973 than in 1972 (Table 4). Following the reasoning used as above, we associate these responses with greater precipitation during the late winter-early spring of 1973 , more available soil N, and greater plant uptake of N. An abundant crop of spring annuals in 1973 (compared with that in 1971 or 1972) manifests the supply of soil N and moisture during that period.

The $\mathbf{N}$ content of mesquite litter did not change from year to year, but that for palo verde was significantly higher in 1973 than in 1972. The high $\mathbf{N}$ concentration of palo verde leaves and flowers in 1973 presumably accounted for this observation.

For both shrubs, $\mathbf{N}$ concentration of litter derived from understory vegetation was significantly higher during 1973 than in preceding years. This probably reflected the wet spring of 1973 , good conditions for $\mathbf{N}$ mineralization and luxurious production of herbaceous understory vegetation, especially annuals. Understory vegetation was high in $\mathrm{N}$ in 1973 and much of the 1973 crop was transferred to litter during the year.

\section{Carbon}

Significant annual differences in $\mathrm{C}$ percentage were detected in leaves of palo verde, in flowers and roots of mesquite, and in understory vegetation of both shrubs and understory litter of mesquite (Table 4). In every case, the differences were small, never exceeding $3 \%$ of the component dry mass. Thus, the differences are of uncertain biological significance. However, because the differences were always associated with components of the shrub system where active metabolism, senescence, or decomposition could be expected, they can be reasonably explained by change in the nonstructural carbohydrate fraction of the components involved.

\section{Implications}

Calculations of $\mathrm{C}: \mathrm{N}$ ratio for the various component with data from the tables demonstrates that litter substrate quality is dynamic in these systems. It follows that decomposition and subsequent nutrient transfer to the underlying soil varies, not only between seasons but perhaps between years as key environmental factors, chiefly amount and timeliness of precipitation, fluctuate to make conditions more or less favorable for litter decomposition and nutrient release. In turn, the pool of available $\mathrm{N}$ may vary to such extent than $\mathbf{N}$ uptake and accumulation by shrubs is altered seasonally and annually.

However, if a significant portion of current demand for $\mathrm{N}$ in perennial herbs and shrubs is satisfied by internal translocation (Clark 1977), then perhaps these species can resupply internal $\mathbf{N}$ levels as external supplies become available without a marked cost in growth and development. Longevity of the major species in the community studied here suggests these species are well adapted to annual and seasonal variations in external $\mathrm{N}$ supply.

The variation in $\mathrm{N}$ and $\mathrm{C}$ level of shrub system components appears complex and presumably involves the interaction of most system processes having to do with gains, losses and translocation 
of elements. Studies which deal with nutrient composition of these shrubs should account for the dynamic nature of these variables in experimental designs.

\section{Literature Cited}

Allison, L.E., W.B. Bollen, and C.D. Moodie. 1965. Total carbon. p. 1346-1366. In: C.A. Black (ed.) Methods of Soil Analysis. Part II. Chemical and Microbiological Properties. Agronomy No. 9. Amer. Soc. of Agron., Madison, Wis.

Barth, R.C., and J.O. Klemmedson. 1978. Shrub-induced spatial patterns of dry matter, nitrogen, and organic carbon. Soil Sci. Soc. Amer. J. 42:804-809.

Barth, R.C., and J.O. Klemmedson. 1982. Amount and distribution of dry matter, nitrogen, and organic carbon in soil-plant systems of mesquite and palo verde. J. Range Manage. 35:412-418.

Bidwell, R.G.S. 1979. Plant physiology. Macmillan Publ. Co., Inc. New York.

Bocock, K.L. 1963. The digestion and assimilation of food by Glomeris. p. 85-91. In: J. Doeksen and J. Van der Drift (eds.) Soil Organisms. North-Holland Publ. Co., Amsterdam.

Bremner, J.M. 1965. Total nitrogen. p. 1149-1179. In: C.A. Black (ed.) Methods of Soil Analysis. Part II. Chemical and Microbiological Properties. Agronomy No. 9. Amer. Soc. of Agron., Madison, Wis.

Clark, F.E. 1977. Internal cycling of ${ }^{15} \mathrm{~N}$ in shortgrass prairie. Ecology 58:1322-1333.

Comanor, P.L., and Staffeldt, E.E. 1978. Decomposition of plant material in two western North American deserts. p. 31-49. In: N.E. West and J. Skujins (eds.) Nitrogen in Desert Ecosystems. Dowden, Hutchinson and Ross, Stroudsburg, Pa.

Coyne, P.I., and C.W. Cook. 1970. Seasonal carbohydrate reserve cycles in eight desert range species. J. Range Manage. 23:438-444.

Culley, M. 1943. Grass grows in summer or not at all. Amer. Hereford J. $34: 8,10$.

Dietz, D.R. 1972. Nutritive value of shrubs. p. 289-302. In: C.M. McKell, et al. (eds.) Wildland Shrubs-Their Biology and Utilization. USDA Forest Ser. Gen. Tech. Rep. INT-1.

Garcia-Moya, E., and C.M. McKell. 1970. Contributions of shrubs to the nitrogen economy of a desert-wash plant community. Ecology 51:81-88.

Grigal, D.F., L.F. Ohmann, and R.B. Brander. 1976. Seasonal dynamics of tall shrubs in northeastern Minnesota: Biomass and nutrient element changes. Forest Sci. 22:195-208.

Hansen, P. 1967. ${ }^{14} \mathrm{C}$-studies on applie trees. II. The influence of season on storage and mobilization of labelled compounds. Physiol. Plants 20:1103-1111.
Hopkins, B. 1966. Vegetation of the Olokemeji Forest Reserve. IV. The litter and soil with special reference to their seasonal changes. J. Ecol. 54:687-703.

Kelley, J.D., and R.W. Shier. 1965. Seasonal changes in the macronutrient composition of leaves and stems of Taxus media. Amer. Soc. Hort. Sci. Pro. 86:809-814.

Klemmedson, J.O.1979. Ecological importance of actinomycete nodulated plants in the western United States. Bot. Gaz. 140(Suppl.):S91-S96.

Martin, S.C. 1964. Some factors affecting vegetation changes on a semidesert grass-shrub cattle range in Arizona. Ph.D. Diss., University of Arizona, Tucson. University Microfilms, Ann Arbor, Mich. (Diss. Abstr. Int. 25:2692).

McKee, H.S. 1962. Nitrogen metabolism in plants. Oxford Univ. Press, London.

McKell, C.M., J.P. Blaisdell and J.R. Goodin (eds.). 1972. Wildland shrubs-their biology and utilization. USDA Forest Serv. Gen. Tech. Rep. INT-1.

Menke, J.W., and M.J. Trlica. 1983. Effects of single and sequential defoliations on the carbohydrate reserves of four range species. J. Range Manage. 36:70-74.

Meyer, Jr., M.M., and W.E. Splittstoesser. 1969. The utilization of carbohydrate and nitrogen reserves in the spring growth of lilac. Physiol. Plant 22:870-879.

Mitchell, H.L. 1936. Trends in the nitrogen, phosphorus, potassium and calcium contents of the leaves of some forest trees during the growing season. Black Rock Forest Papers 1:30-44.

Sampson, A.W., and R. Samisch. 1935. Growth and seasonal changes in composition of oak leaves. Plant Physiol. 10:739-751.

Santos, P.F., and W.G. Whitford. 1981. The effects of microarthopods on litter decomposition in a Chihuahuan Desert ecosystem. Ecology 62:654-663.

Tamm, C.0. 1951. Seasonal variation in composition of birch leaves. Physiol. Plant. 4:461-469.

Tarrant, R.F., K.C. Lu, W.B. Bolen, and J.F. Franklin. 1969. Nitrogen enrichment of two forest ecosystems by red alder. USDA Forest Serv. Pac. Northwest Forest and Range Exp. Sta. Res. Pap. PNW-76.

Tiedemann, A.R., and J.O. Klemmedson. 1973. Effect of mesquite on physical and chemical properties of the soil. J. Range Manage. 26:27-29.

Tukey, H.B. Jr. 1970. Decomposition of litter on the soil surface, p. 611-632. In: C.H. Dickinson and G.L.F. Pugh (eds.) Biology of Plant Litter Decomposition. Vol. 2. Academic Press, London.

Youngberg, C.T., and L. Hu. 1972. Root nodules on mountain mahogany. Forest Sci. 13:211-212. 